\title{
UPAYA PENINGKATAN KOMPETESI PROFESIONALISME GURU IPS DI KABUPATEN JEMBER
}

\author{
Fahrudi Ahwan Ikhsan ${ }^{1}$, Fahmi Arif Kurnianto ${ }^{1}$, Bejo Apriyanto ${ }^{1}$, Elan Artono Nurdin ${ }^{1}$ \\ ${ }^{1}$ Program Studi Pendidikan Geografi, Fakultas Keguruan dan Ilmu Pendidikan, Universitas Jember \\ e-mail: ahwan.fkip@unej.ac.id
}

\begin{abstract}
Abstrak
Penelitian ini bertujuan untuk menjelaskan kondisi profesionalisme dan upaya peningkatan kompetensi guru IPS di Kabupaten Jember. Populasi dalam penelitian ini adalah guru IPS SMP Negeri di Kabupaten Jember sebanyak 184 guru. Teknik pengambilan sampel dilakukan secara random sampling yang berjumlah 55 responden. Metode pengumpulan data dengan kuesioner dan dokumentasi. Analisis data menggunakan deskriptif prosentase. Hasil penelitian yang menunjukkan kondisi kompetensi profesionalisme guru IPS sebagai berikut: penguasaan materi, konsep dan keilmuan yang diampu guru IPS sebesar 87,25\% dalam kategori tinggi; pengembangan materi pembelajaran yang diampu guru IPS secara kreatif sebesar $92,04 \%$ termasuk dalam kategori tinggi; penguasaan standar kompetensi dan kompetensi dasar sebesar 87,05\% termasuk kategori tinggi; pemanfaatan teknologi komunikasi untuk pengembangan diri guru IPS sebesar $86,35 \%$ termasuk dalam kategori tinggi. Secara keseuruhan kondisi kompetensi profesionalisme guru IPS di kabupaten Jember termasuk kategori tinggi yaitu $88,17 \%$, sedangkan upaya peningkatan kompetensi profesionalisme guru IPS sebagai berikut: ikut dalam diklat dan seminar sebesar $66,81 \%$ kategori rendah; mengembangkan silabus dan RPP IPS sebesar 70,50\%; melakukan PTK 48,95\% kategori rendah; mengembangkan ilmu teknologi dalam pembelajaran $74,82 \%$ kategori tinggi. Secara keseluruhan upaya peningkatan kompetensi profesionalisme guru IPS SMP Negeri di Kabupaten Jember sebesar 71,34 termasuk dalam kategori tinggi.
\end{abstract}

Kata Kunci: kompetensi profesionalisme, guru IPS

\section{PENDAHULUAN}

Kompetensi guru sangat diperlukan dalam proses belajar dan mengajar. Hal ini dikarenakan terkait dengan etika profesi yang dikerjakan oleh guru. Kompetensi bukan hanya berorientasi pada keterampilan untuk mengejarkan sesuatu, namun lebih dari makna profesionalisme sebagai guru. Kompetensi akan memberian pengaruh terhadap kepribadian dan pengembangan profesi keguruan. Sumiati (2007) memaparkan bahwa kompetensi guru mencakup empat aspek diantaranya: latar pendidikan, penampilan, kegiatan yang menggunakan prosedur dan teknik, dan pencapaian pada hasil. Kompetensi diwujudkan dalam kerja nyata yang bermanfaat untuk diri sendiri dan lingkungan (Musfah, 2011).

Dinamika yang berkembang sampai hari ini bahwa kompetensi guru memberikan pengaruh dalam proses pembelajaran di kelas. Kemampuan guru yang profesional diperlukan, mengingat dalam konteks tersebut guru bukan hanya bertugas transfer ilmu pengetahuan, namun mendidik tugas utamanya. Kemampuan lebih tersebut wajib dimiliki oleh guru dalam menghasilkan generasi masa depan yang berkualitas. Sanjaya (1992) memaparkan bahwa guru harus memiliki empat kompetensi yang mencakup: kompetensi pedagogik, kompetensi kepribadian, kompetensi profesional, dan kompetensi sosial masyarakat.

Guru mata pelajaran IPS memiliki tugas seperti mata pelajaran lain, namun kompetensi dari guru IPS mempunyai standart tersendiri. Kualitas guru IPS harus mampu menjalankan 
tugas dan kewajiban sebagai seorang pendidik di sekolah. Kualitas guru IPS yang profesional diantaranya: penguasaan ilmu sosial yang luas dan mendalam, penguasaan bidang keguruan mendalam, dan memiliki kepribadian yang menarik atau baik (Hamalik, 1992). Salah satu penyebab yang menunjukkan indikasi kekurang mampuan guru dalam menghasilkan kualitas siswa yang memadai, rendahnya kemampuan dan keterampilan guru dalam mengajar seringkali dianggap faktor penyebab rendahnya pencapaian hasil pendidikan (Agung 2012).

Kompetensi guru IPS sangat dibutuhkan pada jenjang sekolah menengah pertama (SMP). Penerapan kurikulum 2013 mengimplementasikan ilmu sosial yang terdiri dari cabangcabang ilmu geografi, sosiologi, sejarah, dan ekonomi menjadi mata pelajaran IPS terpadu. Problematika yang muncul dari aplikasi IPS terpadu diantaranya lulusan sarjana IPS yang minim dan sosialisasi dari pemerintah yang kurang ke sekolah SMP. Dampak yang ditimbulkan guru IPS sulit meningkatkan profesionalisme dalam bidang ilmu sosial, mengingat di seluruh sekolah SMP Negeri Kabupaten Jember banyak guru bidang studi. Jumlah guru bidang studi yang banyak membuat keprofesionalan guru khususnya ilmu sosial tidak optimal. Penguasaan atas pokok-pokok bahasan materi pelajaran yang terdapat dalam bidang studi IPS menjadi tugas guru dan mutlak diperlukan (Syah, 2010).

Orentasi dari aplikasi pelajaran IPS digunakan untuk mengkaji fenomena dimasa lalu dan mendatang. Penekanan kajian dalam bidang IPS dalam kurikulum perlu dilakukan sebagai pijakan untuk menjawab permasalahan kedua fenomena tersebut. Optimalisasi dari pelajaran IPS bagi siswa untuk menyelesaikan masalah di masa lalu dan sekarang ini. Namun demikian aplikasi dari pelajaran IPS perlu didukung dengan kompetensi dari guru yang relevan dengan bidang IPS.

Berdasarkan data yang diperoleh peneliti dari Dinas Pendidikan Kabupaten Jember bahwa jumlah guru SMP Negeri dan Swasta sebanyak 386 guru, sedangkan jumlah guru IPS se Kabupaten Jember sebanyak 184 guru. Pendidikan terakhir guru rata-rata IPS di Kabupaten Jember adalah strata S1 sejumlah 96\%, sedangkan S2 hanya $4 \%$. Guru pengampu mata pelajaran IPS di sekolah memiliki latar belakang pendidikan yang berbeda, jika dipresentasekan sesuai latar belakang pendidikan diantaranya: geografi $20 \%$, sosiologi $8 \%$, sejarah $21 \%$, ekonomi $34 \%$, PKn $2 \%$, pendidikan agama $2 \%$, dan IPS $13 \%$.

Berdasarkan paparan uraian pada latar belakang tersebut sebagai berikut: (1) Bagaimana kondisi profesionalisme guru IPS di Kabupaten Jember ?; (2) Bagaimana upaya peningkatan kompetensi profesionalisme guru IPS di Kabupaten Jember. Rumusan masalah tersebut menjadi sasaran dalam penelitian ini yang bertujuan: (1) Mengetahui kondisi kompetensi profesionalisme guru IPS di Kabupaten Jember; dan (2) Mengetahui upaya peningkatan kompetensi guru IPS di Kabupaten Jember.

\section{METODE}

Populasi dalam penelitian ini adalah seluruh guru IPS di Kabupaten Jember sejumlah 184. Menurut Arikunto (2006) bahwa sampel adalah sebagian atau wakil populasi yang diteliti. Teknik pengambilan sampel dilakukan secara random sampling. Sampel yang digunakan adalah guru IPS SMP Negeri di Kabupaten Jember diambil 30\% secara acak. Jadi jumlah sampel 55 sampel. Metode pengumpulan data dalam penelitian ini menggunakan kuesioner 
dan dokumentasi. Metode analisis data menggunakan deskriptif prosentase. Variabel dalam penelitian ini terdiri dari dua macam yaitu kondisi profesionalisme guru IPS di Kabupaten Jember dan upaya peningkatan kompetensi profesionalisme guru di Kabupaten Jember.

\section{HASIL DAN PEMBAHASAN}

Penelitian ini bertujuan untuk mengetahui upaya yang dilakukan guru IPS dalam meningkatkan kompetensi profesionalisme di SMP Negeri Kabupaten Jember. Secara astronomis Kabupaten Jember terletak pada titik 1130 30'sampai 114002'30' 'BT dan 7059'6', sampai $8^{0} 33^{\prime} 56^{\prime}$ '. Secara administratif Kabupaten Jember terletak di bagian timur dari Provinsi Jawa Timur.

1. Hasil Analisis Penelitian Kondisi Profesionalisme Guru IPS di Kabupaten Jember

Berdasarkan analisis hasil penelitian menggunakan analisis deskriptif diperoleh gambaran kondisi profesionalisme guru IPS di Kabupaten Jember sebagai berikut: 21 responden $(38,18 \%)$ dengan kategori sangat tinggi, 29 responden $(52,73 \%)$ kategori tinggi, dan 5 responden $(9,09 \%)$ kategori rendah. Dari hasil analisis tersebut dapat disimpulkan bahwa kemampuan guru dalam proses pembelajaran kepada siswa memenuhi standar kompetensi yang ditetapkan dalam standar nasional tinggi yaitu sebesar 88,17\%.

Tabel 1. Kondisi Kompetensi Profesionalisme Guru IPS

\begin{tabular}{ccc}
\hline Kategori & Frekuensi & Prosentase (\%) \\
\hline Sangat Tinggi & 21 & 38,18 \\
Tinggi & 29 & 52,73 \\
Rendah & 5 & 9,09 \\
Sangat Rendah & 0 & 0 \\
Jumlah & 55 & 100 \\
\hline
\end{tabular}

Sumber: Data Primer Penelitian 2017

Variabel kondisi profesionalisme guru IPS secara detail dideskripsikan sesuai kompetensi profesional berikut:

a. Penguasaan materi, konsep, dan keilmuan yang diampu Guru IPS

Jumlah dari 55 responden diperoleh deskripsi tentang penguasaan materi, konsep, dan keilmuan pendukung IPS yang diampu oleh guru sebagai berikut: 45 responden $(81,82 \%)$ dengan kategori sangat tinggi, 5 responden $(9,09 \%)$ kategori tinggi, dan 5 responden $(9,09 \%)$ kategori rendah. Secara klasikal kondisi penguasaan materi, konsepm dan keilmuan yang diampu guru IPS sebesar $(87,25 \%)$ dalam kategori tinggi. Penguasaan yang berhubungan dengan ilmu sosial terpadu tidak mengalami kendala dalam penyampaian kepada siswa. 
Tabel 2. Penguasaan Materi, Konsep, dan Keilmuan yang diampu Guru IPS

\begin{tabular}{ccc}
\hline Kategori & Frekuensi & Prosentase (\%) \\
\hline Sangat Tinggi & 45 & 81,82 \\
Tinggi & 5 & 9,09 \\
Rendah & 5 & 9,09 \\
Sangat Rendah & 0 & 0 \\
Jumlah & 55 & 100 \\
\hline
\end{tabular}

Sumber: Data Primer Penelitian 2017

b. Penguasaan Standar Kompetensi dan Kompetensi Dasar Mata Pelajaran yang diampu Guru IPS

Berdasarkan hasil penelitian diketahui bahwa 55 responden memberikan tanggapan terkait penguasaan standar kompetensi dan kompetensi dasar mata pelajaran yang diampu sebagai berikut: 27 responde $(49,09 \%)$ dengan kategori sangat tinggi, 21 responden $(38,18 \%)$ kategori tinggi, 5 responden $(9,09 \%)$ kategori rendah, dan 2 responden $(3,64 \%)$ kategori sangat rendah. Secara klasikal prosentase penguasaan standar kompetensi dan kompetensi dasar mata pelajaran yang diampu guru IPS sebesar $(87,05 \%)$ termasuk kategori tinggi. Pengembangan perangkat pembelajaran sudah mengikuti perkembangan zaman dan ilmu pengetahuan tentang IPS terpadu pada materi yang diajarkan kepada siswa.

Tabel 3. Penguasaan Standar Kompetensi dan Kompetensi Dasar Pelajaran yang diampu Guru IPS

\begin{tabular}{ccc}
\hline Kategori & Frekuensi & Prosentase (\%) \\
\hline Sangat Tinggi & 27 & 49,09 \\
Tinggi & 21 & 38,18 \\
Rendah & 5 & 9,09 \\
Sangat Rendah & 2 & 3,64 \\
Jumlah & 55 & 100 \\
\hline
\end{tabular}

Sumber: Data Primer Penelitian 2017

c. Pengembangan Materi Pembelajaran yang diampu Guru IPS secara Kreatif

Berdasarkan hasil penelitian pada tabel 4 diketahui bahwa pengembangan materi pembelajaran yang diampu guru IPS secara kreatif sebagai berikut: 29 respoden $(52,73 \%)$ dengan kategori sangat tinggi, 24 responden $(43,64 \%)$ kategori tinggi, 2 reponden $(3,63 \%)$ kategori rendah. Secara klasikal prosentase pengembangan materi pembelajaran yang diampu guru IPS secara kreatif sebesar $(92,04 \%)$ termasuk dalam kategori tinggi. Pengembangan materi dengan permasalahan yang kontekstual di lapangan dilakukan oleh guru IPS agar siswa dapat memahami materi secara mendalam. 
Tabel 4 Pengembangan Materi Pembelajaran yang Diampu Guru IPS secara Kreatif

\begin{tabular}{ccc}
\hline Kategori & Frekuensi & Prosentase (\%) \\
\hline Sangat Tinggi & 29 & 52,73 \\
Tinggi & 24 & 43,64 \\
Rendah & 2 & 3,63 \\
Sangat Rendah & 0 & 0 \\
Jumlah & 55 & 100 \\
\hline
\end{tabular}

Sumber: Data Primer Penelitian 2017

\section{d. Pemanfaatan Teknologi Komunikasi Untuk Pengembangan Diri Guru IPS}

Berdasarkan hasil penelitian pada tabel 5 diketahui bahwa 55 responden diperoleh bahwa tentang pemanfaatan teknologi komunikasi untuk pengembangan diri guru IPS sebagai berikut: 27 responden $(49,09 \%)$ dengan kategori sangat tinggi, 9 responden (16,36\%) tinggi, 19 responden $(34,55 \%)$ kategori rendah. Secara klasikal pemanfaatan teknologi komunikasi untuk pengembangan diri guru IPS sebesar $(86,35 \%)$ termasuk dalam kategori tinggi. Pemanfatan teknologi dalam proses pembelajaran kepada siswa. Contohnya pembelajaran video fenomena geografi dengan peta dan buku yang terkait dengan materi tersebut.

Tabel 5. Pemanfaatan Teknologi Komunikasi untuk Pengembangan Diri Guru IPS

\begin{tabular}{ccc}
\hline Kategori & Frekuensi & Prosentase (\%) \\
\hline Sangat Tinggi & 27 & 49,09 \\
Tinggi & 9 & 16,36 \\
Rendah & 19 & 34,55 \\
Sangat Rendah & 0 & 0 \\
Jumlah & 55 & 100 \\
\hline
\end{tabular}

Sumber: Data Primer Penelitian 2017

2. Hasil Analisis Penelitian Upaya Peningkatan Kompetensi Profesionalisme Guru IPS di Kabupaten Jember

Berdasarkan hasil analisis hasil penelitian dari 55 responden diperoleh deskripsi tentang upaya peningkatan profesionalisme guru IPS di Kabupaten Jember sebagai berikut: 5 responden $(9,09 \%)$ dengan kategori sangat tinggi, 42 responden $(76,36 \%)$ kategori tinggi, 8 responden $(14,55 \%)$ kategori rendah. Kesimpulan yang diperoleh bahwa secara keseluruhan sebesar (71,34\%) memiliki upaya yang tinggi dalam meningkatkan kompetensi profesionalisme dalam bidang IPS terpadu. 
Tabel 6. Upaya Peningkatan Kompetensi Profesionalisme Guru IPS di Kabupaten Jember

\begin{tabular}{ccc}
\hline Kategori & Frekuensi & Prosentase (\%) \\
\hline Sangat Tinggi & 5 & 9,09 \\
Tinggi & 42 & 76,36 \\
Rendah & 8 & 14,55 \\
Sangat Rendah & 0 & 0 \\
Jumlah & 55 & 100 \\
\hline
\end{tabular}

Sumber: Data Primer Penelitian 2017

Variabel yang menjadi pendukung upaya peningkatan kompetensi profesionalisme guru IPS untuk lebih eksplisit dideskripsikan pada upaya peningkatan profesionalisme berikut:

a. Keikutsertaan dalam Diklat, Workshop, Pelatihan, Lokakarya, dan Seminar Keguruan bidang IPS

Berdasarkan hasil penelitian pada tabel 7 dari 55 responden diperoleh keterangan tentang keikutsertaan dalam diklat, workshop, pelatihan, lokakarya, dan seminar keguruan bidang IPS sebagai berikut: 22 responden (40\%) dengan kategori tinggi, 28 responden $(50,91 \%)$ kategori rendah, dan 5 responden $(9,09 \%)$ kategori sangat rendah. Secara klasikal keikutsertaan peningkatan kompetensi profesionalisme guru dalam diklat, workshop, pelatihan, lokakarya, dan seminar keguruan bidang IPS sebesar $(66,81 \%)$ termasuk dalam kategori rendah. Guru IPS di Kabupaten Jember yang tergabung dalam MGMP IPS hanya sebagian saja yang sering mengikuti pelatihan-pelatihan dari Diknas Pendidikan.

Tabel 7. Keikutsertaan dalam Diklat, Workshop, Pelatihan, Lokakarya, dan Seminar Keguruan bidang IPS

\begin{tabular}{ccc}
\hline Kategori & Frekuensi & Prosentase (\%) \\
\hline Sangat Tinggi & 0 & 0 \\
Tinggi & 22 & 40 \\
Rendah & 28 & 50,91 \\
Sangat Rendah & 5 & 9,09 \\
Jumlah & 55 & 100 \\
\hline
\end{tabular}

Sumber: Data Primer Penelitian 2017

b. Melaksanakan Hasil Diklat, Workshop, Pelatihan, Lokakarya, dan Seminar Keguruan bidang IPS

Berdasarkan hasil penelitian pada tabel 8 dari 55 responden bahwa keterangan melaksanakan hasil diklat, workshop, pelatihan, lokakarya, dan seminar keguruan bidang IPS sebagai berikut: 7 responden $(12,73 \%)$ dengan kategori sangat tinggi, 29 responden $(52,73 \%)$ kategori tinggi, 15 responden $(27,27 \%)$ kategori rendah, dan 4 responden $(7,27 \%)$ kategori sangat rendah. Secara klasikal jumlah prosentase dari melaksanakan hasil diklat, workshop, pelatihan, lokakarya, dan seminar keguruan bidang IPS sebesar $(74,84 \%)$ dalam 
kategori tinggi. Workshop, pelatihan, dan seminar akan membantu guru IPS dalam proses pembelajaran di dalam kelas.

Tabel 8. Melaksanakan Hasil Diklat, Workshop, Pelatihan, Lokakarya, dan Seminat Keguruan Bidang IPS

\begin{tabular}{ccc}
\hline Kategori & Frekuensi & Prosentase (\%) \\
\hline Sangat Tinggi & 7 & 12,73 \\
Tinggi & 29 & 52,73 \\
Rendah & 15 & 27,27 \\
Sangat Rendah & 4 & 7,27 \\
Jumlah & 55 & 100 \\
\hline
\end{tabular}

Sumber: Data Primer Penelitian 2017

c. Mengembangkan Silabus dan RPP bidang IPS

Berdasarkan hasil penelitian pada tabel 9 diketahui bahwa 55 respoen tentang deskripsi mengembangkan silabus dan RPP bidang IPS sebagai berikut: 8 responden $(14,55 \%)$ dengan kategori tinggi, 37 responden $(67,27 \%)$ kategori tinggi, 10 responden $(18,18 \%)$ kategori rendah. Secara klasikal upaya peningkatan kompetensi profesionalisme mengembangan silabus dan RPP bidang IPS terpadu adalah sebesar $(70,50 \%)$ termasuk kategori tinggi. Upaya peningkatan kompetensi profesionalisme dengan mengembangkan perangkat RPP secara mandiri. Kendala-kendala dalam penyusunan perangkat pembelajaran dilakukan dengan diskusi bersama teman sejawat dan melalui MGMP IPS Kabupaten Jember.

Tabel 9. Mengembangkan Silabus dan RPP Bidang IPS

\begin{tabular}{ccc}
\hline Kategori & Frekuensi & Prosentase (\%) \\
\hline Sangat Tinggi & 8 & 14,55 \\
Tinggi & 37 & 67,27 \\
Rendah & 10 & 18,18 \\
Sangat Rendah & 0 & 0 \\
Jumlah & 55 & 100 \\
\hline
\end{tabular}

Sumber: Data Primer Penelitian 2017

d. Inovasi Penggunaan Metode Pembelajaran IPS

Berdasarkan hasil penelitian pada tabel 10 diketahui bahwa dari 55 responden tentang tanggapan deskripsi inovasi penggunaan metode pembelajaran IPS sebagai berikut: 22 responden (40\%) dengan kategori sangat tingg, 27 responden $(49,09 \%)$ kategori tinggi, 5 responden $(9,09 \%)$ kategori rendah, dan 1 responden $(1,82 \%)$ kategori sangat rendah. Secara klasikal prosentase upaya peningkatan kompetensi profesionalisme guru dalam inovasi penggunaan metode pembelajaran IPS sebesar $(75,95 \%)$ kategori sangat tinggi. Inovasi yang dilakukan guru dalam pembelajaran IPS terpadu dengan diskusi, observasi, dan kerja kelompok sesuai materi pelajaran yang dibelajarkan oleh guru. 
Tabel 10 Inovasi Penggunaan Metode Pembelajaran IPS

\begin{tabular}{ccc}
\hline Kategori & Frekuensi & Prosentase (\%) \\
\hline Sangat Tinggi & 22 & 40 \\
Tinggi & 27 & 49,09 \\
Rendah & 5 & 9,09 \\
Sangat Rendah & 1 & 1,82 \\
Jumlah & 55 & 100 \\
\hline
\end{tabular}

Sumber: Data Primer Penelitian 2017

\section{e. Melakukan Penelitian Tindakan Kelas Bidang IPS}

Berdasarkan hasil analisis penelitian pada tabel 11 dari 55 responden tentang melakukan penelitian tindakan kelas bidang IPS sebagai berikut: 6 responden $(10,91 \%)$ dengan kategori sangat tinggi, 6 responden $(10,91 \%)$ kategori tinggi, 20 responden $(36,36 \%)$ kategori rendah, dan 23 responden $(41,82 \%)$ kategori sangat rendah. Secara klasikal prosentase peningkatan kompetensi profesionalisme guru dengan melakukan kegiatan penelitian tindakan kelas bidang IPS adalah sebesar $(48,95 \%)$ termasuk kategori rendah. Penelitian tindakan kelas (PTK) bidang IPS jarang dilakukan oleh guru. Selama rentang waktu satu tahun kegiatan penelitian PTK sama sekali tidak pernah dilakukan oleh guru bidang studi IPS.

Tabel 11 Melakukan Penelitian Tindakan Kelas Bidang IPS

\begin{tabular}{ccc}
\hline Kategori & Frekuensi & Prosentase (\%) \\
\hline Sangat Tinggi & 6 & 10,91 \\
Tinggi & 6 & 10,91 \\
Rendah & 20 & 36,36 \\
Sangat Rendah & 23 & 41,82 \\
Jumlah & 55 & 100 \\
\hline
\end{tabular}

Sumber: Data Primer Penelitian 2017

\section{f. Mengembangkan Kemampuan Penguasaan Materi Ajar IPS}

Berdasarkan hasil analisis penelitian pada tabel 12 dari 55 responden tentang mengembangkan kemampuan penguasaan materi ajar IPS sebagai berikut: 36 responden $(65,46 \%)$ dengan kategori sangat tinggi, 14 responden $(24,46 \%)$ kategori tinggi, 5 responden $(9,09 \%)$ kategori rendah. Secara klasikal peningkatan kompetensi profesionalisme guru dengan mengembangkan kemampuan penguasaan materi ajar IPS sebesar $(87,57 \%)$ termasuk kategori tinggi. Mengembangkan kemampuan penguasaan materi ajar IPS dengan melanjutkan sekolah pada jenjang S2 pada bidang IPS dan sertifikasi guru IPS. Guru bidang studi IPS dapat melakukan diskusi dengan temat sejawat, melalui MGMP IPS, dan akses internet jika mengalami kesulitan dalam pemahaman IPS terpadu. 
Tabel 12 Mengembangkan Kemampuan Penguasaan materi Ajar IPS

\begin{tabular}{ccc}
\hline Kategori & Frekuensi & Prosentase (\%) \\
\hline Sangat Tinggi & 36 & 65,46 \\
Tinggi & 14 & 24,46 \\
Rendah & 5 & 9,09 \\
Sangat Rendah & 0 & 0 \\
Jumlah & 55 & 100 \\
\hline
\end{tabular}

Sumber: Data Primer Penelitian 2017

g. Mengembangkan Aplikasi Ilmu Teknologi dalam Pembelajaran IPS

Berdasarakan hasil analisis penelitian pada tabel 13 dari 55 responden tentang mengembangkan aplikasi ilmu teknologi dalam pembelajaran IPS sebagai berikut: 14 responden $(25,45 \%)$ dengan kategori sangat tinggi, 29 responden $(52,773 \%)$ kategori tinggi, 12 responden $(21,82 \%)$ kategori rendah. Secara klasikal prosentase upaya peningkatan kompetensi profesionalisme guru dengan cara mengembangkan kemampuan ilmu teknologi dalam pembelajaran sebesar (74,82\%) termasuk kategori tinggi. Penggunaan teknologi yang berkembang pesat misalnya menggunakan google earth dalam pembelajaran peta yang disesuaikan dengan kebutuhan materi.

Tabel 13 Mengembangkan Aplikasi Ilmu Teknologi dalam Pembelajaran IPS

\begin{tabular}{ccc}
\hline Kategori & Frekuensi & Prosentase (\%) \\
\hline Sangat Tinggi & 14 & 25,45 \\
Tinggi & 29 & 52,73 \\
Rendah & 12 & 21,82 \\
Sangat Rendah & 0 & 0 \\
Jumlah & 55 & 100 \\
\hline
\end{tabular}

Sumber: Data Primer Penelitian 2017

\section{PENUTUP}

Berdasarkan hasil penelitian dan pembahasan bahwa rata-rata guru IPS di Kabupaten Jember memiliki kondisi kompetensi profesionalisme dalam kategori tinggi. Hal ini tidak lepas dari upaya seperti: penguasaan materi, pengembangan perangkat pembelajaran silabus dan RPP, inovasi penggunaan metode pembelajaran IPS, pengembangan aplikasi teknologi ilmu teknologi. Rata-rata upaya peningkatan kompetensi profesionalisme guru IPS untuk sekolah SMP Negeri termasuk kategori tinggi yaitu 71,34\%, namun ada indikator yang upaya peningkatan kompetensinya masih rendah yaitu mengikuti kegiatan diklat, workshop, pelatihan, lokakarya, dan seminar sebesar $66,81 \%$ serta kegiatan penelitian tindakan kelas sebesar $48,95 \%$.

\section{DAFTAR PUSTAKA}

Agung, Iskandar.2012. Continuing Profesional Development (CPD) dan Perubahan Paradigma Sekolah. Jurnal Penelitian Kebijakan Pendidikan Volume 5 Nomor 3, September 2017. 
Arikunto, Suharsimi.2006.Prosedur Penelitian Suatu Pendekatan Praktik. Jakarta: PT Rineka Cipta.

Hamalik, Oemar.1992. Studi Ilmu Pengetahuan Sosial. Bandung: Mandar Maju.

Musfah, Jejen.2011.Peningkatan Kompetensi Guru Melalui Pelatihan dan Sumber Belajar Teori dan Praktik. Jakarta: Kencana.

Sanjaya, Wina.2006.Strategi Pembelajaran berorientasi Standar Proses Pendidikan. Jakarta. Perdana media.

Sumiati dan Asra.2007. Metode Pembelajaran. Bandung: CV Wacana Prima.

Syah, Muhibbin.2010.Psikologi Pendidikan dengan Pendekatan Baru. Bandung: PT Remaja Rosdakarya. 